\title{
OS CAMPOS DE DUNAS MÓVEIS: FUNDAMENTOS DINÂMICOS PARA UM MODELO INTEGRADO DE PLANEJAMENTO E GESTÃO DA ZONA COSTEIRA.*
}

\author{
Antônio J eovah de Andrade Meireles** \\ Edson Vicente da Silva*** \\ Paulo Roberto Lopes Thiers****
}

\section{RESUMO:}

As dunas do litoral cearense foram estudadas de modo a caracterizar parte da dinâmica geoambiental envolvida na evolução geomorfológica da planície costeira. Os dados básicos relacionados com aspectos fisiográficos, classificação dos diversos tipos de corpos eólicos, fontes e transporte de sedimentos e condições climáticas, foram associados a eventos de flutuações do nível relativo do mar e de mudanças climáticas. Aliado aos processos evolutivos propostos, foi possível definir a participação das dunas na regulação do aporte sedimentar para a construção de terraços marinhos holocênicos, origem de lagoas costeiras e morfodinâmica dos sistemas estuarino, lagunar e praial. Ao final, foram elaborados modelos locais para serem utilizados como importantes instrumentos geradores de subsídios técnicos para o planejamento e gestão da zona costeira cearense, nordeste do Brasil.

\section{PALAVRAS-CHAVE:}

Dunas; Evolução geomorfológica; Planejamento e gestão da zona costeira.

\section{ABSTRACT:}

The dunes of the coast of Ceará were studied in way to characterize part of the geoenvironmental dynamics involved in the geomorphologic evolution of the coastal plain. The basic data related to the physiographics aspects, classification of the several types of eolic bodies, sources and transport of sediments and climatic conditions, they were associated to the events of flotations of the sea relative level and to the climatic changes. Combined to the proposed evolutionary processes, was possible to define the participation of the dunes in the regulation of the sedimentary contribution for the construction of holoscenic marine terraces, which is origin of coastal ponds and morphodynamic of the estuary, lagoon and beach systems. At the end, local models were elaborated to be used as important generating instruments of technical subsidies for the planning and administration of the coastal zone from Ceará, northeast of Brazil.

\section{KEY WORDS:}

Dunes; geomorphologic evolution; Planning and administration of the coastal zone

*Trabalho financiado pelo CNPq, CAPES e FUNCAP através de projeto de pesquisa e bolsas de mestrado e doutorado. 


\section{Introdução}

Os eventos glaciais e interglaciais que ocorreram durante o Quaternário, com oscilações do nível do mar na ordem de dezenas e até uma centena de metros, ocasionaram importantes mudanças nos processos geoambientais globais, os quais também provocaram reflexos no litoral brasileiro. Comparando registros de isótopos de oxigênio em sondagens realizadas em diferentes regiões do planeta (incluindo registros nos trópicos, hemisfério Norte e Antártica) SHACKLETON (1987); BROECKER e DENTON (1991); LEDRU, et al. (1996), THOMPSON et al. (1995), entre outros, demonstraram a extensão planetária dos últimos eventos glaciais.

Em áreas mais específicas do litoral cearense foram definidos indicadores geológicos e geomorfológicos de variações do nível do mar relacionados com níveis de erosão escalonados em plataformas de abrasão marinha, paleopavimentos de mangue, terraços marinhos holocênicos e pleistocênicos, antigos corais e gerações de dunas. Foi possível definir 5 eventos eustáticos que fundamentaram a origem de um complexo conjunto de indicadores geoambientais que denunciaram os eventos de mudanças do nível relativo do mar e climáticas na construção da planície costeira cearense.

Estudos realizados por ANGULO e SUGUIO (1995) e ANGULO e LESSA (1997) evidenciaram níveis do mar mais baixos do que os registrados por MARTIN et al. (1986), para a planície costeira do Paraná, durante a última fase regressiva. Propuseram uma curva a partir de datações de vermitídeos (organismos marinhos característicos da zona de praia), a qual não evidenciou as oscilações secundárias registradas na curva proposta por SUGUIO et al. (1985). Aportações realizadas por MARTIN et al. (1998), afirmaram que este tipo de curva, construída somente com um tipo de indicador, não permitiria registrar oscilações de curta duração, as quais constituem características fundamentais de fenômenos naturais, principalmente em ambientes costeiros. Para esses autores, o último evento regressivo foi interrompido por oscilações de alta freqüência, com amplitudes de 2 a $3 \mathrm{~m}$ e duração de, aproximadamente, 300 anos. Os indicadores morfológicos existentes na planície costeira cearense - níveis de erosão escalonados em plataformas de abrasão marinha, paleopavimentos de mangue, terraços marinhos holocênicos e pleistocênicos, antigos corais e gerações de dunas parecem confirmar eventos oscilatórios de alta freqüência do nível relativo do mar, principalmente durante esta última fase regressiva, que teve início há, aproximadamente, $\quad 5.100$ anos A.P (MEIRELES et al., 2000).

A presença de paleoplataformas de abrasão escalonadas, com notchs (entalhes basais) ao longo da planície costeira de Jericoacoara atribuídos a distintos níveis altimétricos do mar (MEIRELES et al. 2003), diferentes da cota atual, foi relacionada com as oscilações de alta freqüência. Estas estruturas de erosão foram estudadas por SUNAMURA (1994) e PIRAZOLLI (1989) e foram utilizadas para a definição de cotas altimétricas do nível do mar diferentes das atuais. Oscilações dessa natureza foram evidenciadas na costa Este brasileira, quando há 4.800 e 2.700 anos A.P. se produziram oscilações da ordem de $3 \mathrm{~m}$ no nível relativo do mar (MARTIN, et al., 1985 e DOMINGUEZ, et al. 1996).

Os campos de dunas do litoral cearense foram também correlacionados com os eventos eustáticos de alta freqüência (MEIRELES, op cit.). A disponibilidade de sedimentos em períodos do nível do mar mais baixos do que o atual, para a formação de campos de dunas contínuos com mais de $20 \mathrm{~km}$ de largura (com altitudes que ultrapassaram $60 \mathrm{~m}$ ) foi utilizada como importante indicador morfológico para 
avaliar alterações do nível relativo do mar. Aliado à ocorrência de eolianitos e a fisiografia do sistema eólico, foram definidas as bases para modelos evolutivos que auxiliaram na composição dos indicadores geoambientais de mudanças do nível relativo do mar e flutuações climáticas durante o último evento glacial e interglacial subseqüente.

A plataforma continental plana e muito extensa possibilitou, em oscilações do nível do mar de pequenas amplitudes, a exposição de extensas áreas com sedimentos representativos de fácies quartzosa e biodetrítica para o transporte eólico. No litoral oeste cearense, eventos desta natureza, que originaram extensos depósitos de sedimentos eólicos, foram representados pela ocorrência de eolianitos em trechos contínuos de até $28 \mathrm{~km}$ (MEIRELES et al., 2000). Associados ao eolianitos, foram registradas ocorrências de depósitos de mangue (com restos vegetais) em áreas atualmente submersas durante a maré baixa e afastados do limite da linha de costa em até $1,2 \mathrm{~km}$ (plataforma associada à zona costeira dos municípios de Icapuí e Camocim).

Mudanças setoriais na temperatura da água do mar estão vinculadas às teleconexões continente-oceano-atmosfera com as altas latitudes (BROECKER, 2001). Desta forma, evidenciaram-se as relações de mudanças de alta freqüência do nível relativo do mar que foram vinculadas a alterações abruptas e cíclicas nas temperaturas dos oceanos e sobreimpostas a ciclos orbitais maiores (ciclos DansgaardOeschger, evento frio Younger Dryas; CACHO, et al. 1999 e MORENO, et al. 2002). Evidências que podem estar representadas pelos componentes morfológicos definidos no litoral cearense.

\section{Metodologia}

Para a definição dos sistemas ambientais (composição de unidades morfológicas) e os aspectos dinâmicos da planície costeira em estudo (figura 1), foram realizados mapeamentos geológicos e geomorfológicos em escala de detalhe. A dinâmica espaciotemporal foi definida a partir de fotografias aéreas, imagens de satélite (Landsat TM 2001 e Ikonos 2003) e monitoramento da dinâmica de migração dos campos de dunas realizado na planície costeira dos municípios de Paracuru e São Gonçalo do Amarante.

Durante as atividades de campo e com a definição das relações de interdependência das dunas com as demais unidades morfológicas e processos ecodinâmicos envolvidos, foram caracterizados os fluxos de matéria e energia responsáveis pela morfogênese local. Procedeu-se desta forma para melhor representar os impactos ambientais das diversas formas de uso vinculadas à dinâmica costeira. Nesta etapa dos trabalhos foram também georreferenciados (GPS Gramin 12 SAD 69) os pontos de descrições dos aspectos locais relacionados com:

i) dinâmica ambiental - interação entre as unidades morfológicas (dunas, terraços marinhos, tabuleiro, lagoas costeiras, canal estuarino e faixa de praia) com as intervenções existentes e propostas;

ii) ecossistemas associados caracterização dos aspectos morfológicos relacionados com aportação de sedimentos e dinâmica dos bancos de areia e,

iii) perfis ao longo dos setores de bypass - realizados sobre o campo de dunas, a faixa de contato entre o campo de dunas e a hidrodinâmica estuarina (margem direita) e linha de praia. 


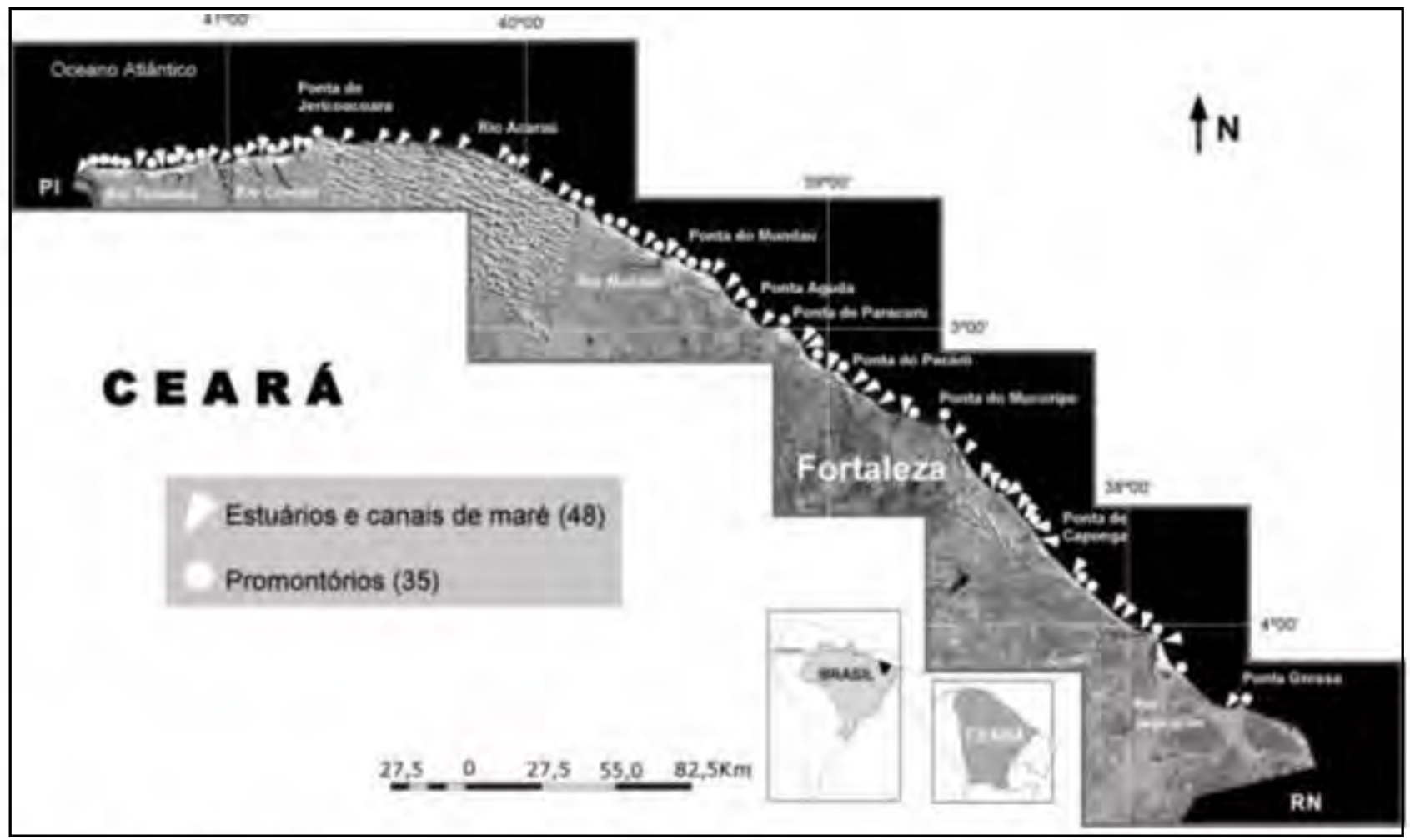

Figura 1 - Localização da área de estudo e pontos relacionados com o sistema de transpasse de sedimentos através dos estuários e promontórios

Para a classificação dos campos de dunas foram utilizados os critérios elaborados por BAGNOLD (1941), CRISTIANSEN et al. (1990), PYE e NEAL (1993), ANGULO (1993), MEIRELES \& SERRA (2002). As ocorrências de campos contínuos, com nítida sobreposição de gerações distintas de dunas, e desta forma com uma elevada complexidade na definição de seqüências temporais, não foram satisfatórias como indicadoras de oscilações de alta freqüência do nível relativo do mar.

\section{Características Climáticas Regionais}

O setor norte do nordeste brasileiro concentra seu período chuvoso entre os meses de fevereiro e maio. Durante esta época, o principal sistema responsável pelas chuvas é a chamada Zona de Convergência Intertropical (ZCIT). Outros sistemas secundários, como, por exemplo, os vórtices ciclônicos de altos níveis, as linhas de instabilidade e as brisas marinhas (estas duas últimas atuam principalmente ao longo da zona costeira), são também responsáveis pelos episódios de precipitações sobre a região. Depois deste período a ZCIT se desloca até o hemisfério norte e as chuvas sobre a região cessam, iniciando-se um longo período de estiagem (MARENGO e UVO, 1997; NOBRE, 1997). Dessa forma, a sazonalidade climática bem definida e a qualidade da estação de chuvas (invernos regulares) sobre a área de estudo, dependem, preponderantemente, das condições atmosféricas e oceânicas, à grande escala, que modulam a intensidade, a fase e o movimento da $\mathrm{ZCIT}$. 
A partir de julho, as precipitaçõs diminuem até o mês de novembro. Os meses de outubro e novembro registraram os mais baixos valores acumulados (FUNCEME, 1996). O primeiro semestre responde por $93 \%$ da precipitação anual.

Com relação à temperatura média mensal, foram registradas oscilações térmicas com médias que variam em torno de $27^{\circ} \mathrm{C}$, com máximas entre 31 a 32ㄷ (FUNCEME, op cit.).

Os índices médios mensais que apresentaram os menores valores de insolação (170 a 180 horas/mês, FUNCEME, op cit.) foram registrados durante o período de maior precipitação, devido a uma maior nebulosidade. Os maiores valores situaramse nos meses com menores índices de precipitação (agosto e outubro) e com valores mais altos de velocidade média dos ventos.

Os ventos apresentam-se no litoral como um importante componente da dinâmica da paisagem e fundamental para a composição dos modelos evolutivos propostos neste artigo. As direções predominantes no litoral cearense são de SE, ESE, E e NE. As médias de velocidade chegam a superar os $4,5 \mathrm{~m} / \mathrm{seg}$. nos meses mais secos. No período de estiagem (segundo semestre) procede-se um predomínio dos ventos de SE (são os ventos mais intensos). No inicio da estação chuvosa, com a chegada da $\mathrm{ZCIT}$, registram-se mudanças na direção dos ventos, passando a predominar os de nordeste.

A Figura 2 mostra a interação dos indicadores meteorológicos (pluviometria, velocidade dos ventos e insolação), importantes para a análise da dinâmica morfogenética litorânea atual. É durante o segundo semestre do ano, com os valores mais elevados de velocidade dos ventos e insolação, e com os índices mais baixos de precipitação, que as dunas migram com maior intensidade. Verificou-se que o processo de avanço dos campos de dunas alcançou média de $12 \mathrm{~m} /$ ano (dunas com faces de avalanche acima de 30m, MEIRELES \& GURGEL JR., 1994) podendo chegar a mais de $35 \mathrm{~m} /$ ano em dunas mais baixas (MAIA, 1998).

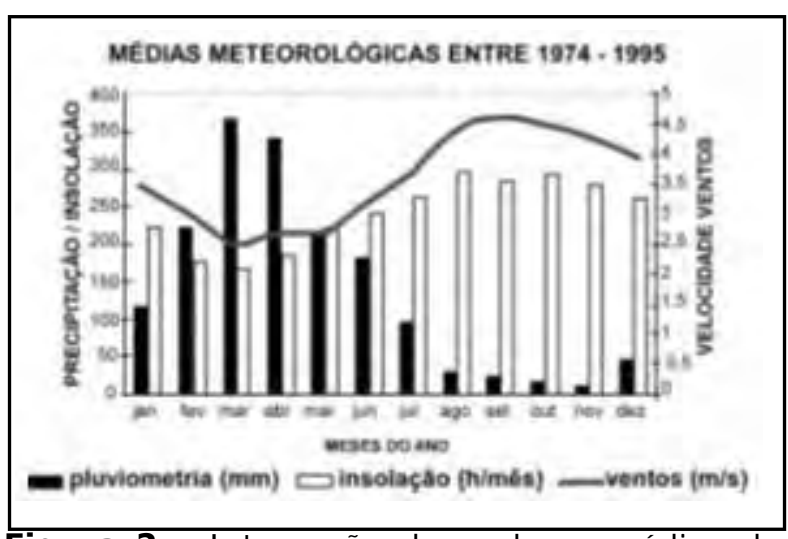

Figura 2 - Integração dos valores médios de precipitação, insolação e velocidade dos ventos para a cidade de Fortaleza/CE (media entre 1974 e 1995, FUNCEME, 1996). O segundo semestre define as condições dinâmicas para a migração dos campos de dunas (baixa precipitação e elevadas insolação e velocidade dos ventos).

\section{A Integração entre os Fluxos Litorâneos}

Uma importante ferramenta para a construção dos modelos locais de evolução da linha de costa foi a definição regional dos fluxos de matéria e energia ao longo da zona costeira. Foram caracterizados a partir da elaboração dos mapas geomorfológicos e geológicos, com a delimitação das morfologias originadas através dos processos de transporte, distribuição e deposição dos sedimentos.

Foram definidos 6 tipos de fluxos de energia ao longo da planície costeira, relacionados diretamente com a participação do campo de dunas na regularização de um aporte de areia para a manutenção da dinâmica praial. A integração definiu-se através da relação dos corpos eólicos com a origem e evolução das falésias, dos terraços marinhos, dos campos de dunas móveis, das lagoas costeiras e interdunares, da faixa de praia e das planícies de marés: 
i) Processo gravitacional relacionado com o transporte de sedimentos nas escarpas das falésias vivas e paleofalésias proporcionando materiais para o desenvolvimento dos terraços marinhos, para a colmatação de lagunas e lagoas e com material inconsolidado para as dunas móveis e a faixa de praia. Nas planícies de Icapuí e Jericoacoara, o fluxo gravitacional originou camadas de aluviões sobre as antigas plataformas de abrasão marinha. Este material foi retrabalhado durante o último evento transgressivo, revelando que parte das plataformas de abrasão dispostas no litoral cearense foi originada durante um evento transgressivo anterior.

ii) Deriva litorânea - se dá ao longo do prisma praial e a plataforma interna (proximal), e está relacionada com o ângulo entre as ondas e a linha de praia, a fisiografia da zona costeira, a direção preferencial dos ventos e a ação das marés e correntes marinhas. Durante a evolução holocênica da planície, não foram produzidas inversões na direção da deriva litoral, tal como evidenciaram as flechas de areia das planícies de Icapuí, Mundaú, Itarema, Acaraú e Camocim, que desde o contato com a paleofalésia, mantiveram sempre a mesma direção de fluxo. A disponibilidade de sedimentos para o transporte litorâneo está diretamente vinculada ao extenso campo de dunas ao longo do litoral nordestino. Proporcionou um aporte regular de areia para a ação dos ventos, desde a linha de praia, durante a maré baixa (estirâncio) e, de forma mais intensa, durante o segundo semestre do ano. Durante os eventos de estiagem, as flechas de areia e campos de dunas que migram sobre as margens dos sistemas fluviomarinhos, associadas às desembocaduras dos rios e canais de maré, interceptam o fluxo fluviomarinho, originando sistemas lacustres. No período de cheias (primeiro semestre), as flechas de areia são rompidas e iniciase o incremento de sedimentos em deriva litorânea ao longo da faixa de praia.

iii) Transporte eólico - vem representado pelo fluxo de sedimentos a partir do estirâncio para o interior do continente, a favor dos ventos dominantes de leste e nordeste. A mobilidade dos sedimentos pela energia eólica deu lugar a grandes campos de dunas, normalmente instalados sobre os terraços marinhos e o tabuleiro prélitorâneo. Nos setores onde se produz o bypass de sedimentos eólicos, através dos estuários e dos promontórios, atuam como importantes veículos de recarga de sedimentos para a continuidade da progradação da planície costeira.

iv) Sistema estuarino - a presença de indicadores morfológicos de eventos eustáticos revelou que as unidades associadas aos canais estuarinos foram inundadas durante os máximos transgressivos. As camadas de paleomangue intercaladas com sedimentos de praia, os arenitos de praia (beachrocks) em suas margens e a evolução dos bancos de areia internos e na desembocadura. Foram os principais elementos morfológicos e dinâmicos (ação das ondas, marés e do fluxo fluvial durante os eventos de enchentes) para a definição deste sistema como fundamental para a composição dos fluxos e aportação de sedimentos para o relevo costeiro. $O$ acesso de campos de dunas que migram na direção dos canais promove a formação de bancos de areia que são transportados para a faixa de praia. Desta forma, é mantido um aporte regulador da dinâmica sedimentar dentro dos canais fluviomarinhos, e associado à evolução morfológica da faixa de praia, quando estes sedimentos alcançam a desembocadura e, assim, são transportados pelas ondas e correntes marinhas.

v) Fluxo flúvio-lagunar - as relações entre a sazonalidade climática, a migração dos campos de dunas e as alterações de alta freqüência do nível relativo do mar, controlam, em grande parte, a evolução dos sistemas fluviais na zona costeira. Os campos de dunas que foram originados durante os eventos regressivos, migraram sobre os canais fluviais e fluviomarinhos, dando lugar a lagunas as quais, nos períodos de maior fluxo fluvial, desobstruíram os canais interceptados e novamente conectaram-se com o mar. Dinâmica diretamente relacionada com eventos de aportação sedimentar para a linha de costa e, conseqüentemente, para a mobilização eólica e aportação de areia para os campos de dunas.

vi) As águas subterrâneas - as características topográficas, climáticas (semi-árido), geológicas (permeabilidade e porosidade da 
Formação Barreiras e dos demais depósitos costeiros) e morfológicas (tabuleiro, terraços marinhos, dunas, entre outras) originaram as condições geoambientais para a participação do aqüífero na origem e desenvolvimento das lagunas, das lagoas interdunares e dos estuários. No caso dos estuários, o aqüífero alimenta de água doce e de sedimentos finos os canais que partem da zona de contato com o tabuleiro e as dunas.

Este conjunto de fluxos integrara-se na composição de processos que favoreceram a origem das unidades morfológicas da planície costeira e no caso específico dos campos de dunas. Proporcionou sedimentos sobre a praia e a plataforma continental interna e os ventos competentes para mobilizá-los continente adentro.

A complexidade interativa do conjunto de fluxos de matéria e energia que transita pela planície costeira, os eventos trans-regressivos do mar e a fisiografia da linha de costa, proporcionaram a origem de um total de 83 setores de bypass de areia para a faixa de praia (figura 1), em uma extensão de, aproximadamente, $573 \mathrm{~km}$ de litoral. Foram caracterizados em setores de promontórios ( 35 setores) e nas margens de estuários e canais de maré (48 setores). Quando esses setores foram ocupados pela expansão das cidades e das vilas de pescadores (hotéis, loteamentos e vias de acesso) e pela implantação de projetos portuários e agroindustriais, a faixa de praia à jusante da deriva litorânea foi intensamente erosionada (promontórios de Caponga, do Mucuripe, do Pecém, de Paracurú e Aguda).

Estas intervenções atuaram de forma a bloquear o acesso de grandes volumes de areia à faixa de estirâncio, acarretando a origem de extensas áreas em elevado processo de degradação ambiental, vinculadas a um déficit progressivo de sedimentos no sistema praial. Procedeu-se, inicialmente, o soterramento de equipamentos públicos e privados sobre as dunas, seguido de erosão severa na faixa de praia.

\section{Dinâmica Litorânea em Zonas Bypass}

A planície costeira cearense está sendo submetida a uma série de intervenções antrópicas em áreas destinadas à regulação dos processos litorâneos. Foram relacionadas basicamente com a implantação de equipamentos públicos e privados em locais que interferiram diretamente nos processos sedimentares, morfológicos, hidrodinâmicos e oceanográficos responsáveis pela dinâmica não erosiva da faixa de praia.

Unidades morfológicas caracterizadas pela dispersão de sedimentos, alimentadoras de material arenoso para o sistema praial e reguladoras dos fluxos de energia (dunas móveis, flechas e bancos de areia e terraços marinhos associados aos promontórios e margens dos rios), dos quais, foram, em muitos casos, utilizadas de forma inadequada. Como conseqüência, foi induzido um novo comportamento evolutivo, em grande parte orientado para o avanço da erosão (MEIRELES et al., 1991; MORAIS \& MEIRELES, 1992; MAIA, 1998; MEIRELES \& MORAIS, 1994).

Foi através da ação das marés, das ondas e dos ventos predominantes de leste e nordeste, que se desenvolveu a deriva litorânea dos sedimentos regionalmente de leste para oeste. Durante o período de maré baixa, os ventos transportam parte dos sedimentos sobre o estirâncio para a berma e daí para o interior do continente, dando origem às dunas móveis, isto se o volume de areia for suficiente e os ventos apresentarem competência para mobilizá-lo. Ao serem edificadas as estruturas dunares (barcanas, barcanóides, parabólicas, transversais, dômicas, entre outras) e com a continuidade do processo de migração, as que alcançam canais fluviomarinhos são consumidas pela hidrodinâmica estuarina, com os sedimentos originando bancos de areia no leito do canal. Ao atingirem a desembocadura e lançados para a linha de praia, o transporte sedimentar é regido pelo sistema de correntes litorâneas (novamente pela ação das ondas, marés e correntes marinhas).

De outra forma, com as dunas migrando sobre os promontórios, logo à frente os sedimentos retornam para a linha de praia, de onde participam do transporte longitudinal proporcionado pelas correntes litorâneas. Os promontórios existentes ao longo do litoral cearense representam importantes 
zonas de transpasse de sedimentos (bypass de areia). Devido o transporte litorâneo desenvolver-se de leste para oeste, os setores representados pela praia, berma, dunas em contato com o estirâncio e campos de dunas imediatamente à oeste dos promontórios foram, em grande parte, edificados pelo fornecimento de areia proveniente das dunas que sobrepassam os pontais.
A síntese dos processos morfodinâmicos produziu modelos regionais para representar a dinâmica evolutiva de áreas relacionadas com o bypass de sedimentos eólicos através dos promontórios e canais estuarinos (Figura 3). Foram elaborados a partir de mapeamentos geológicos e geomorfológicos, monitoramento espaciotemporal dos campos de dunas móveis e diagnósticos ambientais em áreas submetidas a intensos processos erosivos (MEIRELES, 2001).

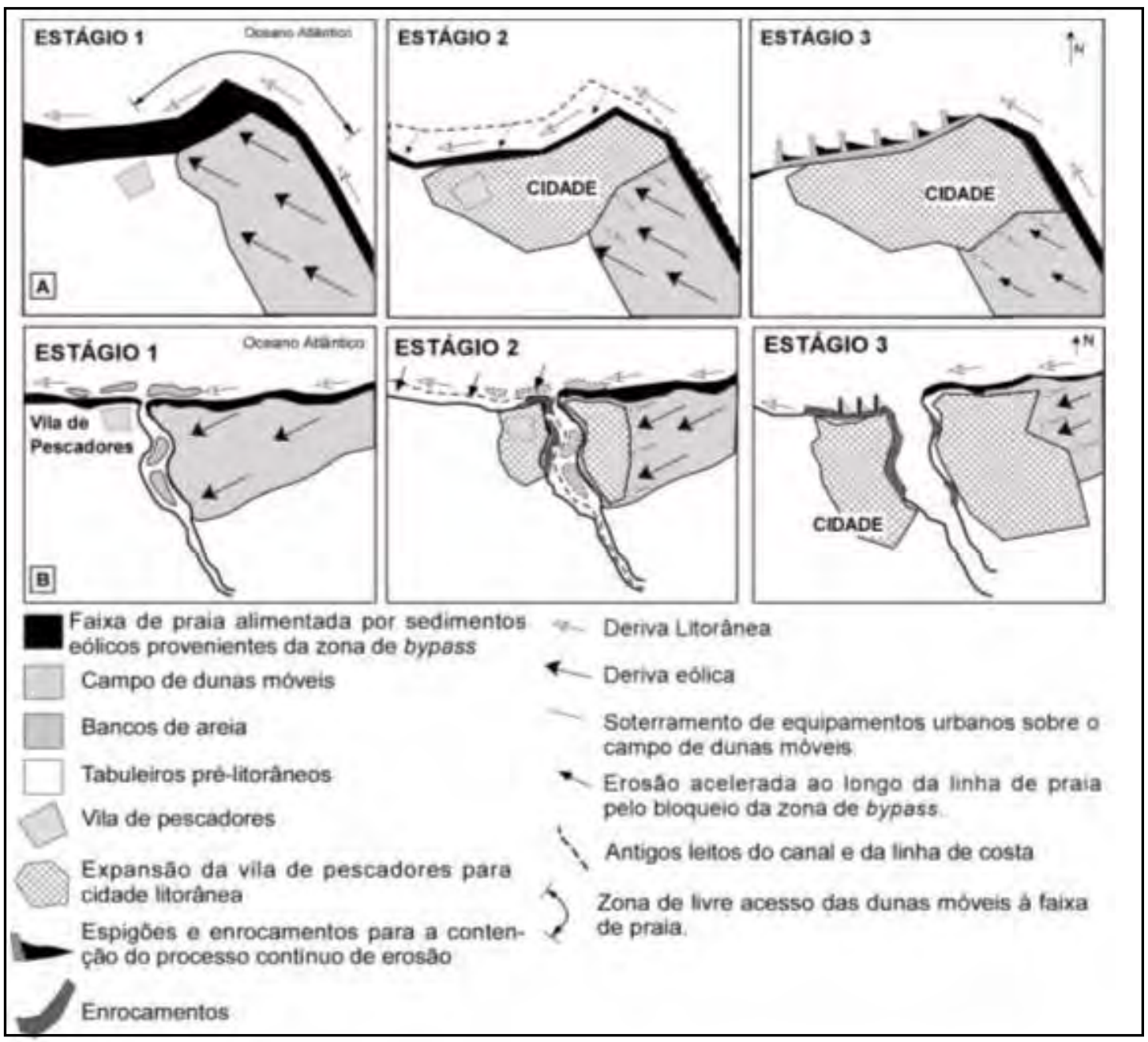

Figura 3 - Modelo para representar a dinâmica evolutiva dos campos de dunas em promontórios (A) e canais estuarinos (B), com a expansão urbana em setores destinados à regulação dos processos morfológicos da linha da costa. 
É através da relação de interdependência entre morfologias definidas, como praia, dunas móveis, canais estuarinos e promontórios, que se processa parte da dinâmica costeira, com a manutenção de um fluxo contínuo de areia para a faixa de praia através da participação de sedimentos provenientes dos campos de dunas móveis. As planícies fluviomarinhas e os promontórios envolvidos com o transpasse de areia para a linha de praia proporcionam a integração entre os fluxos eólico, gravitacional, estuarino e de correntes marinas (ondas e marés). Foram os responsáveis, em grande parte, pela origem dos campos de dunas e pela contínua transformação morfológica da planície costeira, mesmo quando submetidas aos eventos de mudanças do nível relativo do mar.

Quando o homem interfere nestes processos, modificando a trajetória, a energia envolvida e o volume de areia em transporte, iniciase uma nova dinâmica, normalmente regida pelo predomínio de fenômenos erosivos. Foram intensificados quando grandes volumes de areia, que antes transitavam pela planície costeira, na forma de dunas, foram desviados ou fixados pela expansão urbana, loteamentos mal planejados e as construções de hotéis, e, assim, impedidos de alcançarem a faixa de praia.

A implantação de equipamentos que inviabilizaram esse fluxo de sedimentos acarretou rápidas mudanças no padrão morfodinâmico, alterando a quantidade de areia que define perfis de praia de acordo com a ação do clima de ondas. Com a continuidade do transporte de sedimentos pela ação das ondas e sem uma reposição a partir dos setores de bypass, foi desencadeada a erosão acelerada.

A seguir, serão definidos os principais aspectos ambientais ao longo do promontório do Pecém e do sistema fluviomarinho do rio Mundaú, litoral oeste do estado do Ceará. A figura 4 representa as principais morfologias da planície costeira que abrange as duas áreas de estudo.

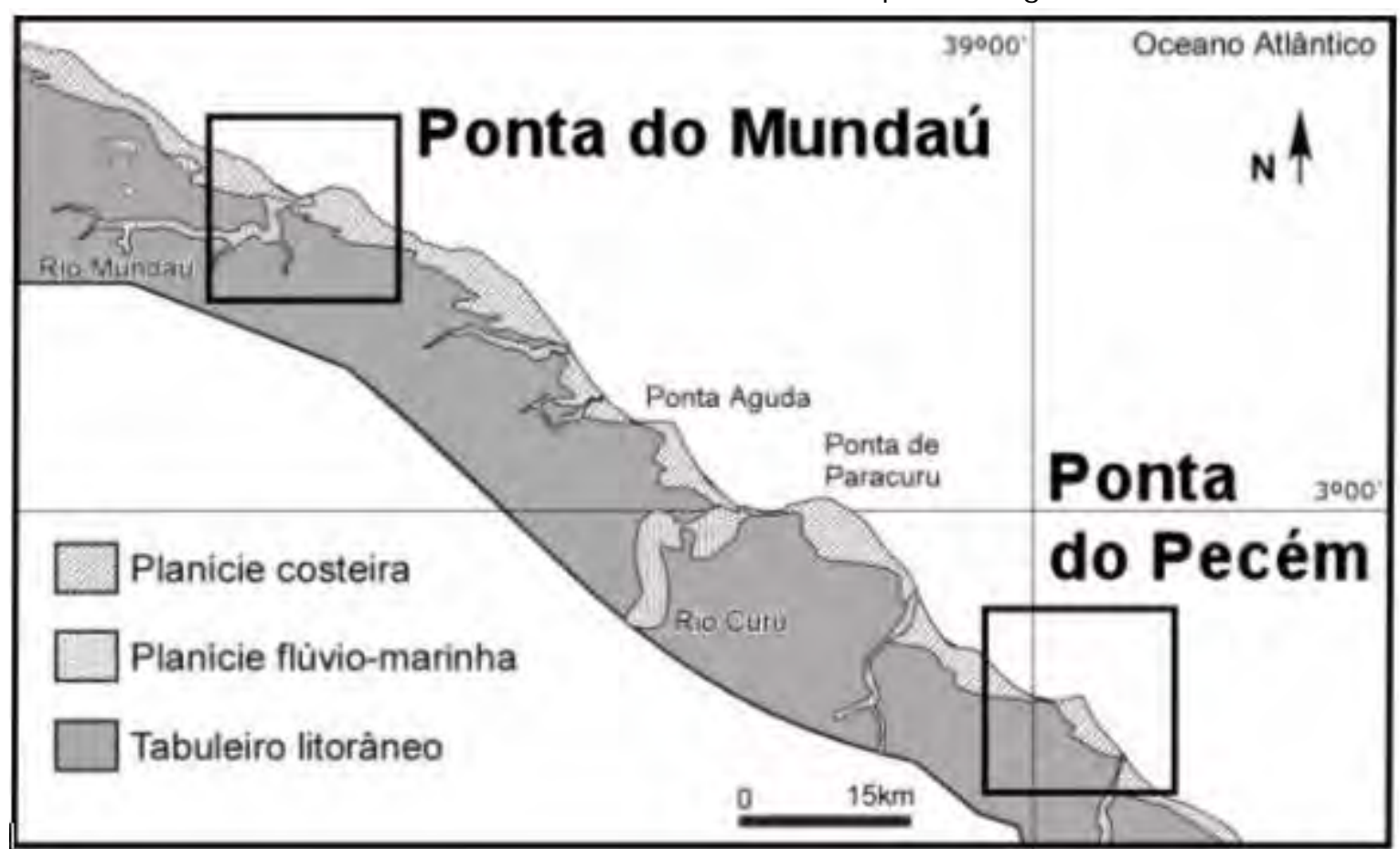

Figura 4 - Mapa geomorfológico simplificado do setor da planície costeira que compreende as duas áreas de estudo. 


\section{A planície costeira do Pecém}

A utilização de recobrimentos aerofotogramétricos e imagens de satélite de diferentes épocas possibilitou a realização de estudos que envolveram a determinação da evolução da linha de costa. Os critérios utilizados foram relacionados com a evolução da zona de berma, ocupação de unidades de domínio das ondas e marés e de domínio do campo de dunas móveis. Os indicadores morfológicos de evolução da dinâmica litorânea foram associados ao comportamento erosivo da faixa de praia em um setor de aproximadamente $3,0 \mathrm{~km}$ de litoral.

A dinâmica morfológica da linha de costa foi intensamente alterada devido às intervenções sistematicamente localizadas nas dunas e no setor de berma diante da vila de pescadores. A urbanização da duna frontal à linha de preamar, justamente a que se dirigia para alimentar a praia, impossibilitou o acesso de grandes volumes de areia para a dinâmica existente no prisma praial. Com isso, as ondas iniciaram a remobilização dos sedimentos existentes mais à jusante (à oeste do promontório) e posicionados na berma localizada diante do núcleo urbano. A partir de então, foi originado um déficit de areia, evidenciado pelo deslocamento da duna para o interior do continente e o consumo do depósito de sedimentos vinculado ao setor de berma. Desta forma, a erosão foi, gradativamente, sendo acelerada, provocando impactos ambientais relacionados com a supressão de uma larga faixa de berma. Atingiu valores críticos a partir de 1999, quando bloqueado, por completo, o bypass de sedimentos das dunas (obas portuárias) e a migração dos bancos de areia ao longo da faixa de estirâncio (construção do molhe provisório de embarque do Complexo Portuário e Industrial do Pecém).

A figura 4 representa o promontório do Pecém em 1987, com o campo de dunas alcançando a faixa de praia em uma extensão de $580 \mathrm{~m}$. Ainda evidenciou-se o acesso de sedimentos, que atuavam como material regulador dos processos litorâneos, suprindo com areia a faixa de praia diante da vila. A partir de 1991, as dunas foram ocupadas por casas de veraneio, desencadeando o bloqueio de parte dos sedimentos e o início de um processo contínuo de erosão da faixa de praia.

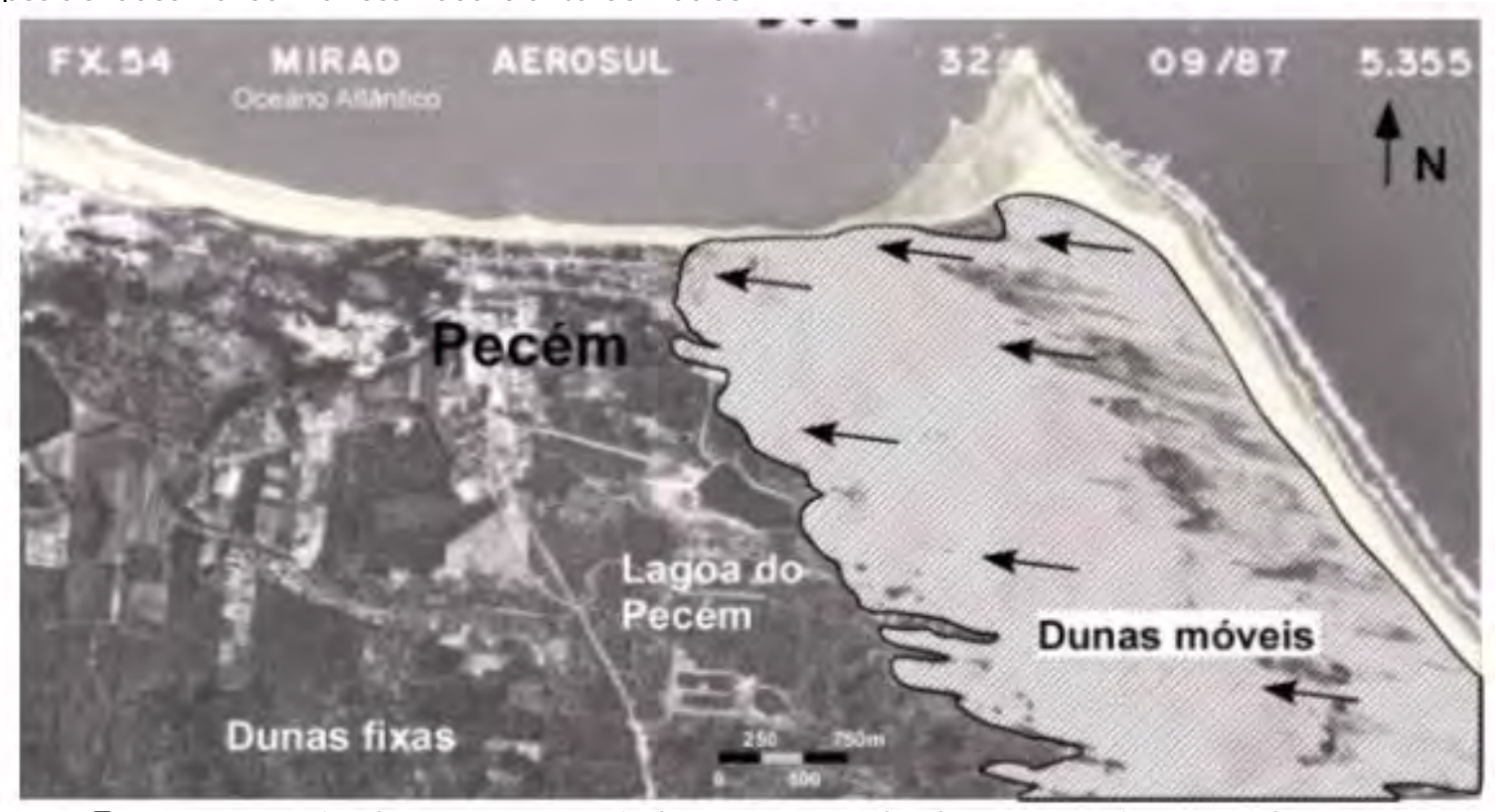

Figura 5 - Promontório do Pecém associado ao campo de dunas móveis antes da construção do Complexo Portuário e Industrial do Pecém. As dunas ao atingirem a faixa de praia mantinham um volume de areia para a deriva litorânea (fotografia aérea de 1987). 
Essa dinâmica proporcionou um recuo de $200 \mathrm{~m}$ da linha de praia continente adentro, em uma extensão de, aproximadamente, 2.750m, entre o período de 1958 e 1999 . Foi erosionada uma área de, aproximadamente, $412.500 \mathrm{~m}^{2}$. A remoção da zona de berma, com altura média de 1,2 m (altura da escarpa de praia), representou um volume de sedimentos remobilizados (e não reposto pela deriva litorânea) na ordem de $495.000 m^{3}$ (Figura 5).

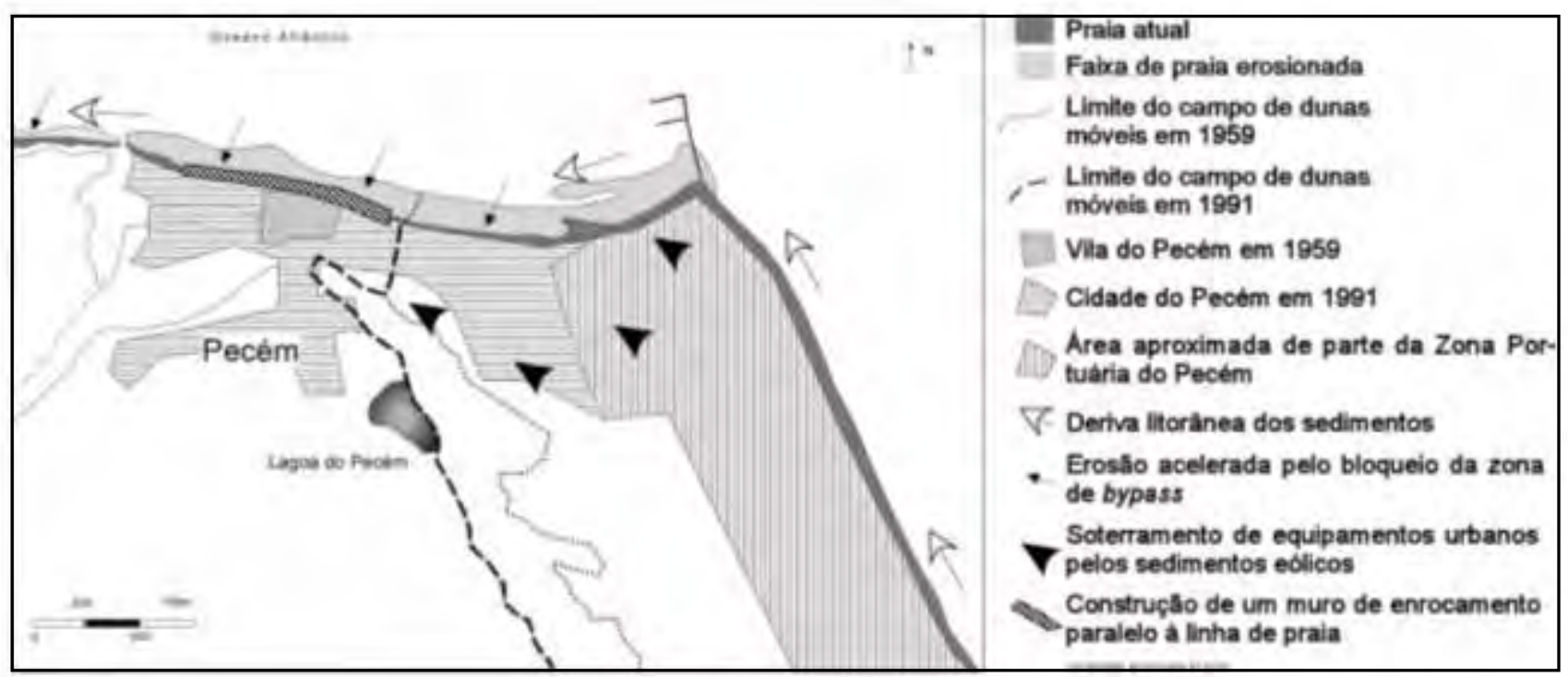

Figura 6 - Evolução da faixa de praia após o bloqueio do bypass de sedimentos pela expansão da vila de pescadores (casas de segunda residência) e implantação do Complexo Portuário e Industrial do Pecém

As dunas foram ocupadas em, aproxim adam ente, $515250 \mathrm{~m}^{2}$, dado referente ao ano de 2000. A partir de 2002, foram completamente urbanizadas pela expansão dos loteamentos e implantação de obras de infraestrutura do Porto do Pecém.

As residências e vias de acesso construídas sobre as dunas foram, sistematicamente, soterradas, principalmente durante o segundo semestre do ano, quando os ventos são mais intensos (podendo alcançar rajadas com mais de $18 \mathrm{~m} / \mathrm{s}$ ). As casas de segunda residência dispostas na berma foram danificadas, e várias completamente destruídas pelo ataque direto das ondas ( 19 casas de segunda residência foram seriamente danificadas através de recalques, solapamentos

\section{e desmoronamentos).}

As medidas de contenção (construção de uma bateria de espigões e um muro de enrocamento de, aproximadamente, $800 \mathrm{~m}$ diante da vila) não apresentaram resultados satisfatórios. As ondas danificaram essas estruturas, e o acesso à zona de estirâncio somente pode ser realizado durante o período de maré baixa. O porto das jangadas foi suprimido, com os pescadores ancorando suas embarcações sobre a via pública.

Após a retirada do molhe provisório de embarque, verificou-se a retomada do transporte de areia diante da vila (ALBUQUERQUE, 2005). Durante os trabalhos de campo, verificou-se que se tratava de um volume antes acumulado à montante do molhe 
provisório e, como atualmente não se verifica o bypass de sedimentos, é provável que, a médio prazo, seja retomada a dinâmica francamente erosiva.

A figura 7 mostra um modelo simplificado da dinâmica associada às dunas reguladoras dos processos litorâneos na planície costeira do Pecém. As variações das marés interagem com a duna, mobilizando areia para a deriva litorânea pelo ataque direto das ondas durante a maré alta. Com a ocupação das dunas, promoveu-se um colapso de sedimentos, impossibilitando a reposição de sedimentos provenientes do transpasse através do promontório, o que desencadeou um processo erosivo progressivo e contínuo.

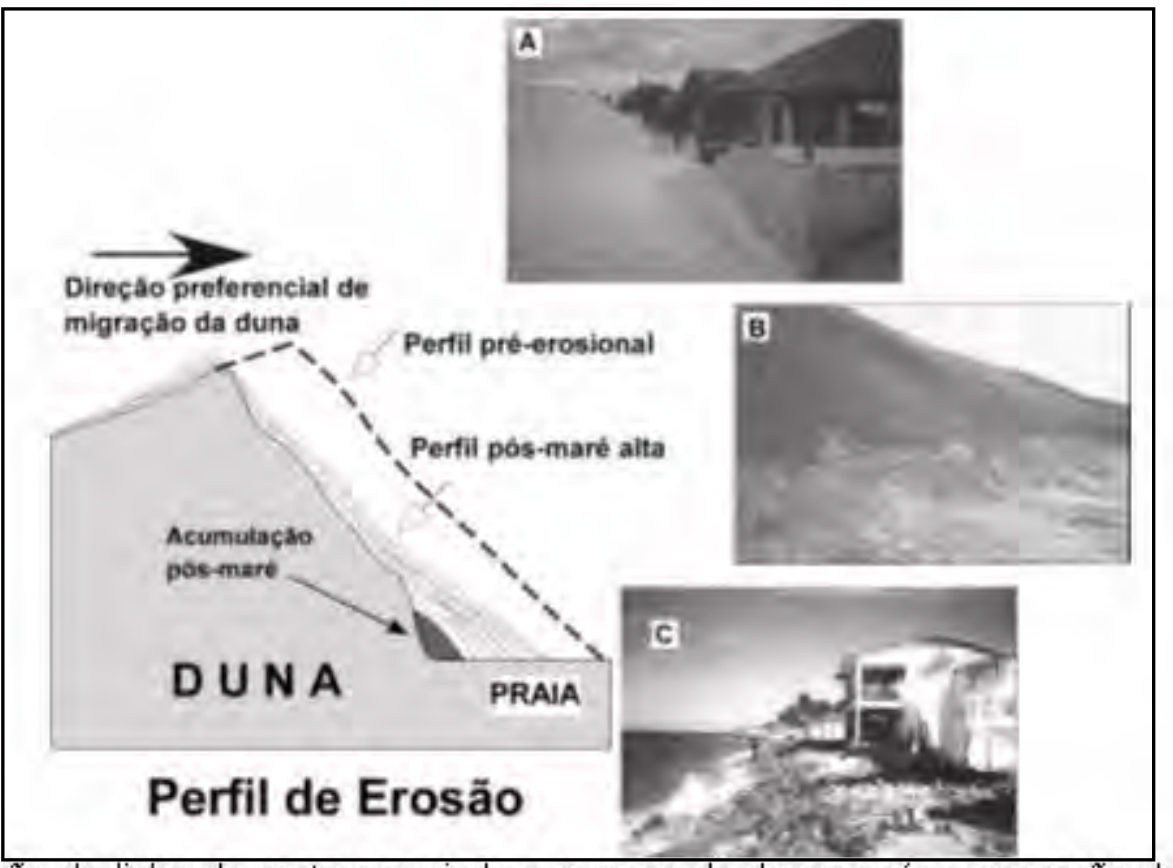

Figura 7 - Evoluçã̃o da linha de costa associada a campos de dunas após a ocupação dos setores de bypass de sedimentos: A) soterramento dos equipamentos urbanos; B) déficit de areia na linha de costa e C) erosão da faixa de praia com danos aos equipamentos públicos e privados.

\section{Bypass de sedimentos na margem direita do estuário do rio Mundaú}

O estuário do rio Mundaú representa um importante complexo geodinâmico associado a um conjunto morfológico composto pela faixa de praia, gerações de dunas, lagoas costeiras, manguezais, rochas de praia (beachrocks), planície fluviomarinha, terraços marinhos e tabuleiro pré-litorâneo. A figura 8 mostra o campo de dunas móveis que atua na dinâmica costeira local.
A dinâmica de migração do campo de dunas está relacionada com dois setores de aportação de sedimentos na direção da faixa de praia e margem direita do rio Mundaú:

i) Dunas que migram sobre o promontório e atingem diretamente a linha de costa (setores a): fornecem sedimentos para a origem dos bancos de areia quando alcançadas pelas ondas. Ao ser gerado um volume de sedimentos para a faixa de praia, proporciona a origem de flechas de areia na desembocadura do rio, 
Os campos de dunas móveis: fundamentos dinâmicos para um modelos integrado de planejamento e gestão da zona costeira, pp. 101 - 119

orientando a evolução morfológica deste setor do canal e de parte da plataforma proximal e;

ii) Dunas que alcançam a margem direita do rio Mundaú (setor b): ao interagirem com a dinâmica das marés ao longo do canal estuarino e durante os eventos de cheia, forneceram sedimentos para a formação de bancos de areia. Os sedimentos oriundos das dunas móveis foram também utilizados para a origem da flecha de areia que se encontra, atualmente, na margem esquerda do rio.

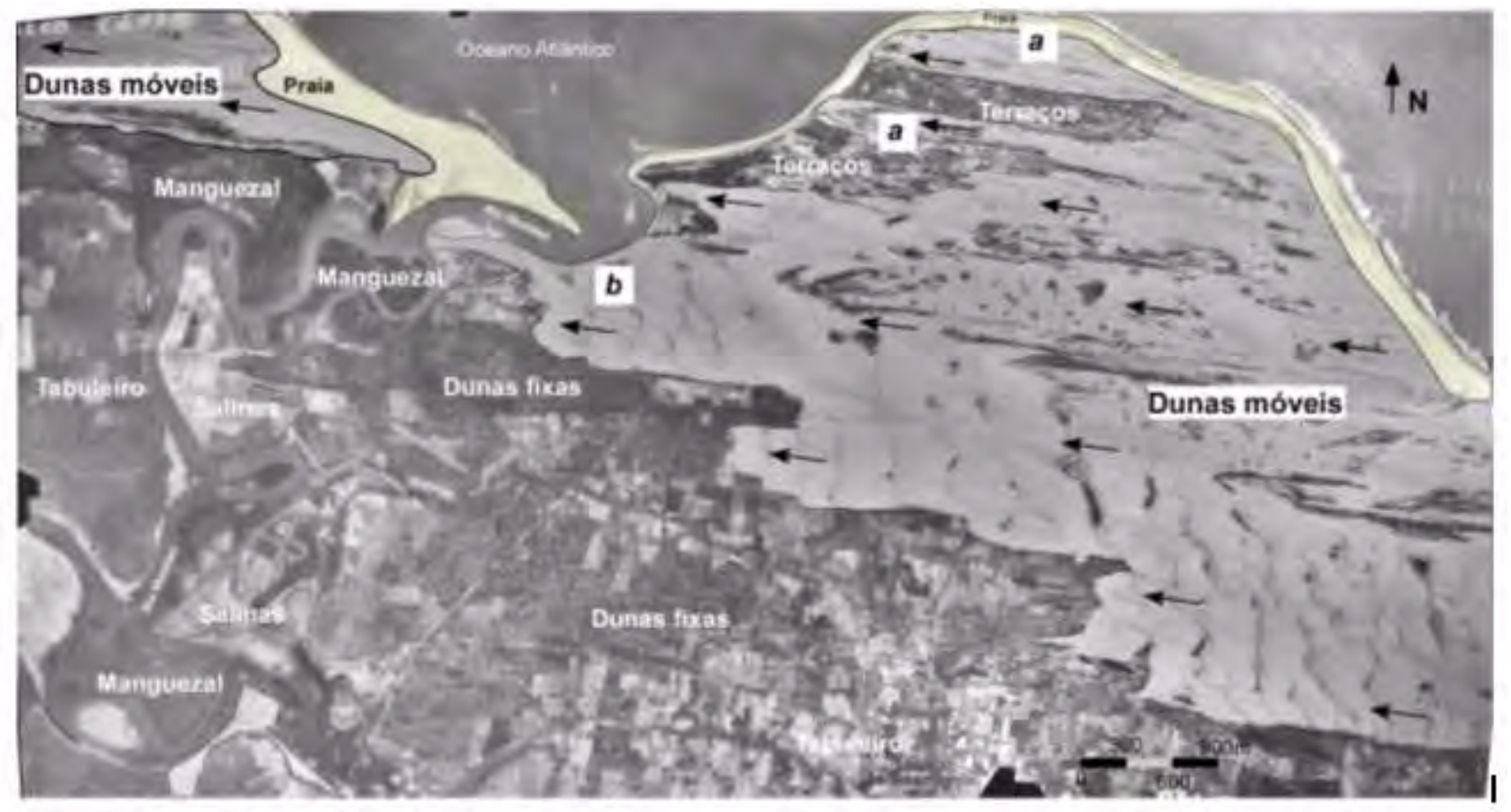

Figura 8 - Fotografia aérea de 1969 da desembocadura do rio Mundaú (escala 1:25,000, composição realizada através do software Panorama Maker 3.0$)$. As flechas representam a direção de migração dos campos de dunas.

A expansão da vila de pescadores foi iniciada a partir da utilização de áreas destinadas aos processos morfogenéticos locais, o que acarretou uma série de impactos ambientais negativos e vinculados à erosão da linha de praia. Foram relacionados à ocupação das dunas móveis com a construção de casas de veraneio e vias de acesso.

Verificou-se que a dinâmica das margens do estuário foi regida pela migração dos bancos de areia (dispostos no canal principal, em gamboas e na desembocadura), os quais foram originados, em grande parte, pelo aporte de sedimentos provenientes do campo de dunas que acessam a margem direita do estuário. A evolução de suas margens, através do deslocamento dos bancos de areia internos ao canal principal (pelo fluxo e refluxo das marés) e pelo aporte sedimentar (entrada do campo de dunas pela margem direita), caracterizou-se pela ciclicidade entre os períodos de enchente 
e estiagem. Durante o primeiro semestre, período de maior vazão fluvial, parte dos bancos de areia foram erodidos e os sedimentos transportados para a faixa de praia. Durante a estiagem (segundo semestre), as dunas migram sobre a margem direita e, assoreando o canal, contribuem para a formação de outra geração de bancos de areia, que são transportados pela dinâmica das marés.

A implantação de empreendimentos hoteleiros e vias de acesso sobre o campo de dunas (está prevista a implantação de 4 hotéis cinco estrelas, 3 campos de golfe e lagos artificiais; COEMA, 2004) certamente bloqueará o fluxo de sedimentos proveniente do campo de dunas móveis na direção do canal estuarino. A projeção dos equipamentos planejados com a dinâmica atual promoverá uma série de alterações ambientais. As principais foram associadas com os seguintes aspectos dinâmicos:

i) Bloqueio do fluxo natural de sedimentos eólicos: com a ocupação do campo de dunas móveis que migra na direção da margem direita do rio, será originado um déficit de sedimentos para a origem dos bancos de areia;

ii) Evolução dos bancos de areia: com o aporte atual de sedimentos eólicos na direção do rio, foram constituídos bancos de areia que, ao serem submetidos ao fluxo das marés, atuam como reguladores de um aporte sazonal de sedimentos para a linha de praia, minimizando os efeitos erosivos nas margens do canal estuarino e na faixa de praia localizada à oeste da desembocadura;

iii) Erosão acelerada ao longo da margem direita do estuário: com a diminuição do aporte de sedimentos, através do bloqueio promovido pelos equipamentos projetados, será instalada uma nova dinâmica sedimentar. Será regida pela ação do fluxo hidrodinâmico no setor mais côncavo do meandro localizado nas proximidades da desembocadura. Trata-se naturalmente, de um setor erosivo do canal, o qual, com o déficit de areia projetado, será submetido a um contínuo e severo processo erosivo;

iv) Danos aos equipamentos urbanos existentes: a evolução do meandro localizado nas proximidades da desembocadura foi o responsável pela erosão da margem direita do estuário. Desde 1994, foram registrados eventos erosivos que provocaram a destruição de casas e vias de acesso;

v) Soterramento dos equipamentos projetados: com um campo de dunas com mais de $12 \mathrm{~km}$ de extensão migrado na direção do setor de bypass de areia (local projetado para os empreendimentos), os equipamentos urbanos projetados serão, constantemente, submetidos ao soterramento pelas areias transportadas pelo vento;

vi) Impermeabilização do campo de dunas: o setor projetado para a implantação dos equipamentos hoteleiros está associado diretamente, a uma importante zona de recarga do aqüífero dunar. Trata-se de uma excelente reserva de água doce para a localidade de Mundaú e que se vincula, também, ao aporte de água doce para o ecossistema manguezal;

vii) Danos aos exutórios de água doce: as dunas que bordejam a margem direita do estuário são associadas a uma série de pequenas nascentes que originam riachos e lagoas interdunares conectados com o rio Mundaú. Ao ser impermeabilizado, o setor de dunas projetado para o complexo hoteleiro, serão gerados danos ambientais associados com a diminuição do volume e da qualidade da água armazenada no aqüífero dunar e, conseqüentemente, extinção dos canais afluentes do rio e das lagoas interdunares. É importante salientar que as alterações na qualidade da água, pela salinização do aqüífero também estarão vinculadas à sazonalidade: durante as oscilações diárias e mensais da maré, e aporte da água doce (fluvial e pluvial) nos períodos de estiagem e de maiores precipitações pluviométricas;

viii) Danos à fauna e flora: com o déficit 
de areia relacionado com a ocupação das dunas que alcançam a margem direita do rio, os bancos de areia serão seriamente afetados pela erosão. A fonte de sedimentos para a origem destas morfologias é, atualmente, relacionada com os sedimentos provenientes das dunas. Esses bancos de areia evoluíram para setores do ecossistema manguezal e, inclusive, estão associados a áreas de refúgio e alimento para as aves migratórias;

Os sedimentos que retornam para a zona de estirâncio via canal estuarino, alimentam a deriva litorânea e mantêm um perfil de acordo com a dinâmica imposta pelo clima de ondas, notadamente sem a presença de processos erosivos contínuos.
Desta forma, as intervenções direcionadas para o bloqueio do bypass poderão, ainda, regionalizar os efeitos erosivos, alterando a dinâmica dos processos morfogenéticos na plataforma continental proximal e nas praias mais à oeste da desembocadura do rio Mundaú.

A figura 9 apresenta uma seqüência de dunas relacionada com a dinâmica de aporte de sedimentos para a linha de praia. Evidencia o acesso de dunas móveis à faixa de praia após contornarem promontórios $(A)$; duna barcana dentro de um canal de maré $(B)$; um modelo simplificado da dinâmica evolutiva das dunas que acessam a faixa de praia após contornarem promontórios e acessarem canais estuarinos (C) e quando interceptam canais de maré durante os eventos de estiagem (D).

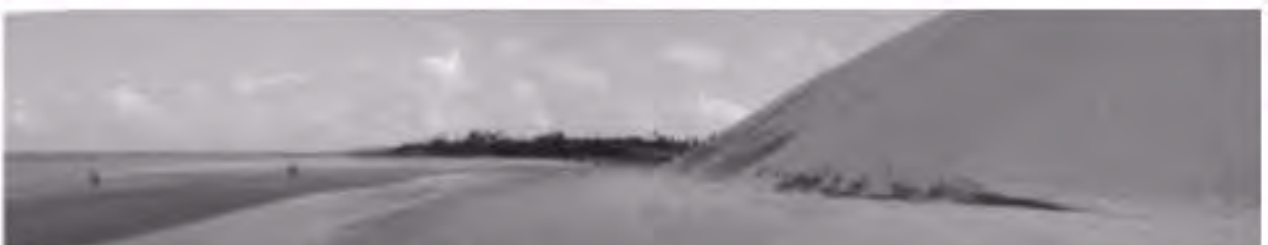

A
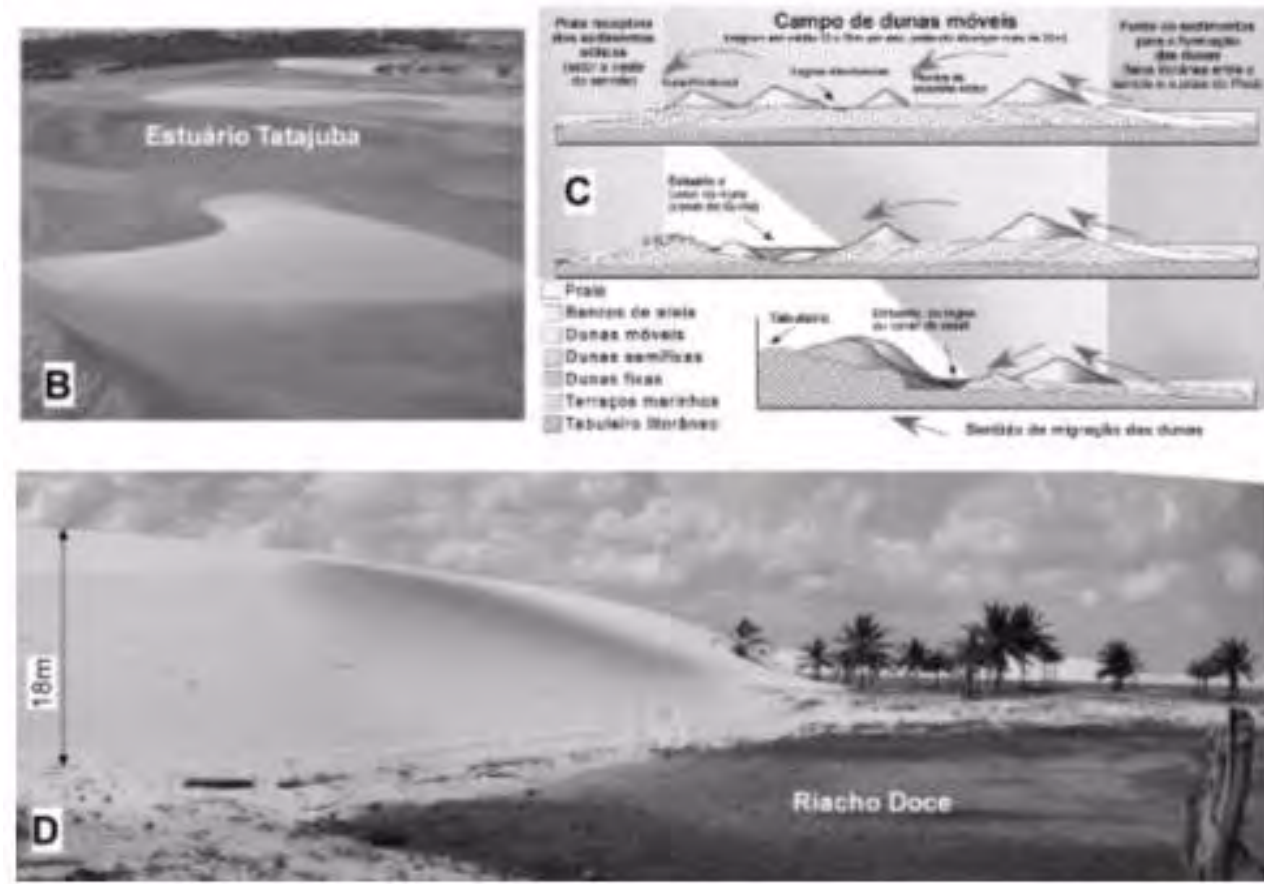

Figura 9 - Migração dos campos de dunas na direção da faixa de praia e de canais de maré: dunas que contornam promontórios e atingem a faixa de praia $(A)$; duna barcana dentro de um canal de maré (B); um modelo simplificado da dinâmica evolutiva das dunas que acessam a faixa de praia após c o $\mathrm{ntor}$ a $\mathrm{r}$ e m promontórios acessarem canais estuarinos (C) e quando interceptam canais de maré durante os eventos de estiagem (D). 


\section{Recomendações Finais e Conclusões}

Como resultado, verificou-se que as dunas móveis presentes ao longo de, praticamente, toda planície costeira cearense controlaram os processos geodinâmicos da linha de costa, dentro de um padrão de comportamento e dependência de acordo com a evolução morfogenética das zonas de bypass de sedimentos.

A plataforma continental plana e muito extensa possibilitou, em oscilações do nível do mar de pequenas amplitudes, a exposição de extensas áreas com sedimentos representativos de fácies quartzosa e biodetrítica para o transporte eólico. No litoral leste cearense, eventos desta natureza, que originaram extensos depósitos de sedimentos eólicos, foram representados pela ocorrência de eolianitos, quando biodetritos da plataforma continental foram mobilizados para o interior do continente, ao serem expostos em eventos regressivos holocênicos (MEIRELES \& RUBIO, 2000).

A partir da dinâmica de aporte de sedimentos para a zona costeira em setores de promontórios e canais de maré, foram definidos critérios para a classificação de áreas de risco. Foram agrupados através da evolução espaciotemporal dos fluxos hidrodinâmico (estuarino), eólico (migração dos campos de dunas), litorâneo (ação das ondas e marés na linha de costa) e subterrâneo (disponibilidade de água no lençol freático e curso da hidrodinâmica do aqüífero). As unidades geoambientais foram caracterizadas de modo a orientarem medidas de planejamento e gestão dos setores de bypass de sedimentos:

i) Campo de dunas móveis que migram na direção das margens dos estuários: unidade geoambiental de elevado risco para a ocupação. O bloqueio do fluxo de areia para a margem direita dos rios promoverá um colapso de sedimentos e conseqüentemente, erosão severa em suas margens, podendo alcançar setores já urbanizados;

ii) Campos de dunas móveis que contornam promontórios: unidade geoambiental de elevado risco para ocupação. A expansão das cidades litorâneas e a construção de hotéis sobre dunas móveis associadas aos promontórios promoveu a erosão na faixa de praia devido ao déficit de areia originado pelo bloqueio do fluxo de sedimentos na direção da linha de costa;

iii) Dunas fixas: unidade ambiental de preservação permanente. Deverá ser integralmente preservada de ações que interfiram em seus aspectos morfológicos, paisagísticos e ecológicos;

iv) Bancos e flechas de areia: unidades em grande parte responsáveis pela evolução morfológica e ecodinâmica do sistema estuarino e da faixa de praia, e de elevado risco de ocupação. Com o bloqueio da fonte de areia proveniente das dunas móveis, serão diretamente afetados pelo déficit de sedimentos, promovendo alterações na hidrodinâmica do canal e no aporte de areia para as praias e plataforma continental proximal;

v) Faixa de praia: tanto as associadas às margens dos canais estuarinos como à barlavento das dunas sobre promontórios, serão afetadas pelo déficit de sedimentos provocado pelo bloqueio do transpasse ao longo do campo de dunas móveis. Unidade morfológica de elevado risco e associada a mudanças na dinâmica evolutiva com o incremento da erosão costeira;

$$
\text { vi) Lençol freático: }
$$
impermeabilização do campo de dunas (construção de hotéis e expansão das cidades litorâneas sobre o campo de dunas), afetará a quantidade e a qualidade da água no subsolo, o fluxo hidrodinâmico e a 
pressão hidrostática exercida pelo aqüífero na zona de contado entre a água doce e a salgada. Serão induzidos riscos de salinização do lençol freático e de extinção das lagoas interdunares e das nascentes de riachos que alimentam com água doce o ecossistema manguezal;

$$
\text { vii) Terraços }
$$

$$
\text { marinhos }
$$

fluviomarinhos: unidades morfológicas de médio a baixo risco nos setores afastados da linha de praia e margem dos canais e ecossistema manguezal. Favoráveis a riscos de contaminação do lençol freático por efluentes domiciliares e industriais e à erosão de acordo com a dinâmica de transporte sedimentar por deriva litorânea e evolução dos bancos de areia nos canais estuarinos, e;

viii) Tabuleiro pré-litorâneo: desde que evidenciados os riscos de contaminação do lençol freático, de impermeabilização das zonas de recarga, preservação da mata de tabuleiro, de setores de domínio dos campos de dunas móveis e de atividades tradicionais de agricultura e pesca, representa a unidade morfológica mais adequada para a implantação de equipamentos turísticos e ampliação das cidades e vilas de pescadores.

Intervenções no sentido de ocupar estes setores, inviabilizando o fornecimento de areia para a faixa de praia, elevaram a complexidade das reações ambientais, principalmente as relacionadas com a desconfiguração morfológica das dunas, da faixa de praia e dos canais estuarinos. O sistema costeiro foi conduzido para um novo nível de comportamento, regido pela erosão contínua. Em várias áreas do litoral cearense a ocupação dos campos de dunas responsáveis pela manutenção de um aporte regulador de sedimentos para os processos litorâneos originou erosão acelerada. As mais críticas ocorreram nas praias de Barra Nova/Beberibe, Caponga/ Cascavel, litoral metropolitano de Fortaleza, I parana/Caucaia, Pecém/São Gonçalo do Amarante, Paracuru e Alagoinha/Paraipaba. Os impactos elevaram o grau de incerteza na previsão das reações ambientais, uma vez que acarretaram mudanças morfológicas rápidas, com trechos fragmentados de erosão acelerada, mas, com a continuidade do déficit de sedimentos pela ocupação das zonas de transpasse de areia para a faixa de praia, poderão conectar-se e evoluírem para áreas de erosão contínua.

A integração dos processos morfogenéticos com evidências de mudanças do nível relativo do mar de alta freqüência, definidos por MEIRELES (2001) para o litoral cearense, deverá ainda ser vinculada às mudanças setoriais na temperatura da água do mar (teleconexões continente-oceanoatmosfera) de altas latitudes, como as oscilações abruptas e cíclicas na temperatura dos oceanos, sobreimpostas a ciclos orbitais maiores. A variabilidade e interconexão dos fenômenos naturais que se sucedem em altas latitudes e em outras regiões do planeta (Zona de Convergência Intertropical ZCIT, Oscilação Norte Atlântica NOA, El Nino, La Nina, entre outros) são fatores fundamentais para um modelo mais preciso para explicar a origem e evolução dos campos de dunas do nordeste brasileiro.

Portanto, os setores que atualmente regulam o aporte de sedimentos para a linha de costa (bypass de areia em promontórios e canais de maré) deverão ser preservados. Favorecem a manutenção de um estado dinâmico sem a presença de eventos erosivos severos, e será mantido um fluxo contínuo e regulador do aporte de sedimentos para a faixa de praia. 


\section{Bibliografia}

ALBUQUERQUE, M. F. C. Zona costeira do Pecém: de colônia de pescador a região portuária. Dissert., Universidade Estadual do Ceará UECE, Mestrado Acadêmico em Geografia, 2005, 212p.

ANGULO, R.J. e LESSA, G.C. The Brasilian sealevel curves: a critical review with enphasis on tre curves fron Paranaguá and Cananeia regions. Marine Geology, 140 (1997) 141-166.

ANGULO, R.J . e SUGUIO, K. Re-evaluation of the Holocene sea-level maxime for the state of Paraná, Brasil. Palaeogeography, Palaeoclimatic, Papaleoecology, 113 (1995), 385-393.

ANGULO, R.J. Morfologia e gênese das dunas frontais do litoral do Estado do Paraná. Rev. Bras. Geoc. 23 (1), 1993, 68-80.

BAGNOLD, R.A. The physics of blownsand and desert dune. 1a edição., London 1941, 265p.

BROECKER, W. S. Was the medieval warm period global? Science, 291, 2001, 1497-1499

BROECKER, W.S. e DENTON, G.H. ¿Que mecanismo gobierna los ciclos glaciares? Libros de Investigación y Ciencia - Scientific American, 1991, 18-27p.

CACHO, I., GRIMALT, J. O., PELEJ ERO, C., CANALS, M., SIERRO, F. J., FLORES, J. A., e SHACKLETON, N. J. Dansgaard-Oeschger and Heinrich event imprints in Alboran Sea temperatures. Paleoceanography 14, 1999, 698-705.

CRISTIANSEN, C.; DALSGAARD, K.; MOLLER, J.T. e BOWMAN, A.D. Coastal dune in denwark chronology in relation to sea level. In: Bakker, T.W., Jungerives, P.D. y Klijn, J.A. (ed.), Dunes of European coasts-Geomorphology- HydrologySoils.. Journal of the international society of Soil Science, Supplement 18, 1990, 61-70.

FUNCEME Fundação Cearense de Meteorologia e Recursos Naturais - Governo do Estado do Ceará. Relatório interno, Fortaleza/Ceará, 1996.

LEDRU, M. P.; BRAGA, M.P.; SOUBIES, F.; FOURNIER, M. MARTIN, L. SUGUIO, K. e Turq, B. The last 50.000 years in the neotropcs
(Southern Brazil): Evolution of vegetation and clin ate; Palaeogeographiy, Palaeoclimatology, Palaeoecology 123, (1996), 239-257.

MAIA, L.P. Procesos costeros y balance sedimentario a lo largo de Fortaleza NE-Brasil implicaciones para una gestión costera ordenada. Tesis de doctorado, Universidad de Barcelona, 1998, 268p.

MARTIN, L.; BITTENCOURT, A.C.SP.; DOMINGUES, J.M.L.; FLEXOR, J.M. e SUGUIO, K. Oscillations or not oscilations, thet is the questions: Comment on Angulo, R. J. and Lessa G. C. « The Brazilian sea-level curves. A critical review with emphasis on the curves from the Paranaguá and Cananéia Regions» [Mar. Geol. 140, 141-166]. Marine Geology, 150: (1998) 179-187.

MARTIN, L.; SUGUIO, K. e FLEXOR, J.M. Shell miodens as a source for additional information in Holocene shoreline and sea-level reconstruction: example form the coast of Brazil. In: Sea-level research: a manual for the collection and evaluation of data. Ed. by Orson van de Palassche; 18: (1986) 503-523.

MEIRELES, A.J.A. \& GURGEL Jr., J.B. Dinâmica costeira em áreas com dunas móveis associadas a promontórios, ao longo do litoral cearense. $38^{\circ}$ Cong. Bras. de Geologia, Balneário de Camboriú/SC. Anais...v1, 1994, 403-404p.

MEIRELES, A.J.A. \& MORAIS, J.O. Compartimentação geológica, processos dinâmicos e uso e ocupação da Planície Costeira de Parajuru, município de Beberibe, litoral leste do Estado do Ceará. Revista de Geologia, V7, 1994, 69-81p.

MEIRELES, A.J.A. \& RUBIO, P.R. Geomorfología litoral: una propuesta metodológica sistémica en la llanura costera de Ceará, nordeste de Brasil. Revista de Geografia, Universitat de Barcelona, España; 32/33, 1999, 165-182.

MEIRELES, A.J.A. e SERRA, J.R. Evolução paleogeográfica da planície costeira de 
Jericoacoara/Ceará. Mercator, Revista de Geografia da UFC, vol. 1 (1), 2002, 79-94

Meireles, A.J.A.; Serra, J.R. e Montori, C.B (2002)

MEIRELES, A.J.A.; SERRA, J.R. e SABADIA, J.A.B. Sea level changes in Jericoacoara- Ceará coastal plain. The Mediterranean, News/wtter, 22, 2000, 87-88.

MORAIS, J.O \& MEIRELES, A.J.A. Riscos geológicos associados a dinâmica costeira na Praia de Caponga, município de Cascavel, Estado do Ceará. Revista de Geologia 1992, 5: 139-144.

MORENO, A., CACHO, I., CANALS, M., PRINS, M. A., SÁNCHEZ-GOÑI, M. F., GRIMALT, J. O., and WELTJE, G. J. Saharan dust transport and high latitude glacial climatic variability: the Alboran Sea record. Quaternary Research 58, 2002, 318328

NOBRE, P. A variabilidade interanual do Atlântico Tropical e sua influência no clima da América do Sul. Centro de Previsão de Tempo e Estudos Climáticos - Instituto Nacional de Pesquisas Espaciais (CPTEC/INPE), 1997, 49p.
PYE, $K \&$ \&EAL, A. Late holocene dune formation on the Sfton coast, northwest England. In: The dynamics and environmental context of aeolian sedimentary systems; ed. by K. Pye. Geological Society Sedimentary; Special Publication no 72; 1993, 201-218.

SHACKLETON, N.J. (1987): Oxigen isotope, ice and sea-level. Quaternary Science Reviews 6: 183-190.

SUGUIO, K.; MARTIN, L.; BITTENCOURT, A.C.S.P.; DOMINGUEZ, J.M.L.; FLEXOR, J.M. \& Azevedo, A.E.G. Flutuações do nível relativo do mar durante o Quaternário Superior ao longo do litoral brasileiro e suas implicações na sedimentação costeira. Rev. Bras. Geoc., 15 (4): 1985, 273-286.

THOMPSON, L.G., MOSLEY-THOMPSON, E., DAVIS, M.E., LIN, P.N., HENDERSON, K.A. COLE-DAI, J. BOLZAN, J.F., LIU, K.B. Late Glacial Stage and Holocene Tropical Ice Core Records fron Huascarán, Peru. Science 269, 1995, 46-50. 
